\title{
Lawsuit rekindles gene-patent debate
}

\section{Criticism of exclusive licences puts university policies in the spotlight.}

A court case in New York next week could have widespread implications for gene patenting. The judge will consider a lawsuit over a discovery that was made in university labs and ended as a lucrative test monopoly for a diagnostics company. Although universities in the United States are expected to bring federally funded discoveries to the public by partnering with industry, the practice of granting exclusive licences to test for disease-related genes has faced mounting criticism.

The legal battle is the latest revolving around Myriad Genetics of Salt Lake City, Utah, and seven patents on the BRCA1 and BRCA2 genes, which are linked to most of the inherited cases of breast cancer. Myriad is co-owner of some of the patents with the University of Utah in Salt Lake City - where part of the research took place with federal money - and has exclusive rights to conduct diagnostic tests on the genes.

Many people are intently watching the outcome, because thousands of genes have been patented in the United States. "The potential impact goes beyond breast-cancer testing," says Hans Sauer, a patent lawyer with the Biotechnology Industry Organization in Washington DC.

Myriad charges about US $\$ 3,000$ to sequence a patient's $B R C A$ genes in search of cancerrelated mutations. The company has actively enforced its patents, including shutting down $B R C A$ research at university laboratories.

In May 2009, the Public Patent Foundation and the American Civil Liberties Union filed a lawsuit charging that it is unconstitutional to patent a natural gene, and that Myriad's monopoly has limited clinicians from offering alternative tests. Myriad's head general counsel, Richard Marsh, dis-
"There isn't a technology-transfer office that isn't aware of the Myriad case."

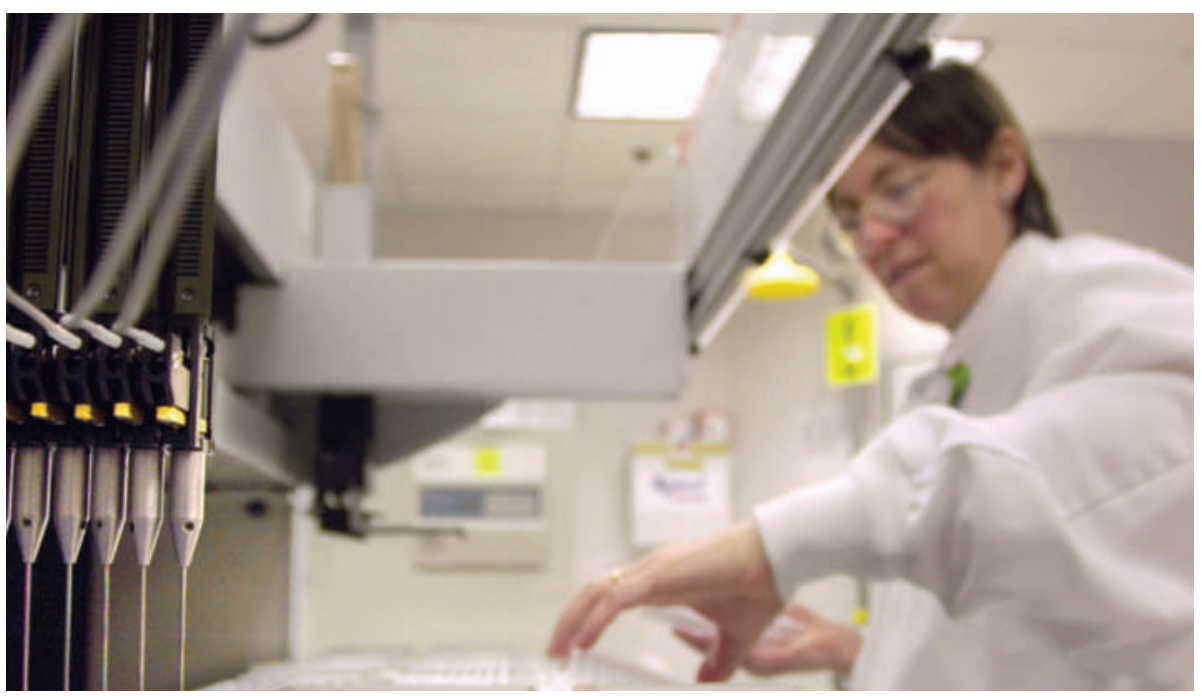

Myriad Genetics is the sole source of US tests for BRCA genes that are linked to breast-cancer risk.

But diagnostic monopolies have continued to proliferate. Some blame university technology-transfer offices, which own most gene patents and often grant exclusive licences to private companies.

In October 2009, for instance, Myriad purchased an exclusive licence for the PALB2 gene, which can be used to detect the hereditary risk of developing pancreatic cancer, from Johns Hopkins University in Baltimore, Maryland. Marsh says that Myriad would not have accepted a non-exclusive licence because it is expensive to run clinical studies, sign deals with insurers and "convince medical societies to change their guidelines to test for a genetic predisposition to a disease".

But there is little evidence that exclusive licences are putes all points. "We think their legal argument is misplaced and erroneous," he says.

After the hearing, scheduled for 2 February, a federal judge will decide whether to move the case to trial. The alternative is to issue a summary judgement in favour of one side, but such an outcome would no doubt be appealed to the Supreme Court.

Myriad's broad patents are outliers - today, patents are usually issued instead for specific gene mutations. Indeed, in 2008 the company was forced to narrow its patent claims in Europe to three mutations that are prevalent in Ashkenazi Jewish families. needed to develop diagnostics, says Robert Cook-Deegan of the Institute for Genome Sciences and Policy at Duke University in Durham, North Carolina. In a review of genetic tests for ten medical conditions, Cook-Deegan has found that the exclusive rights holder was the last one on the market and used its position to shut down small labs that had developed their own tests without any expectation of exclusivity.

Equally to blame, some say, are investigators who fail to take an active role in the technologytransfer process. For instance, Michael Goggins, a gastroenterologist at Johns Hopkins, was one of the discoverers of PALB2 but didn't play a part in the licensing strategy for the gene. "We just left that to our university representatives," he says. "We're too busy as scientists." Wesley Blakeslee, head of technology transfer at Johns Hopkins, says that the university did the best it could to get its invention to the marketplace.

The US National Institutes of Health (NIH) and the Association of University Technology Managers encourage the use of non-exclusive licences for gene diagnostics, which are currently standard for NIH employees licensing such technology and could soon become so for those receiving NIH grants at other institutions. At a meeting that starts on 4 February, the Secretary's Advisory Committee on Genetics, Health, and Society at the US Department of Health and Human Services will discuss whether grantees should be required to issue non-exclusive licences for gene-based diagnostics, except if they can demonstrate the high cost of test development.

Robin Rasor, director of licensing at the University of Michigan in Ann Arbor, says that requiring non-exclusive licenses would be a mistake. Exclusive licences can come with development milestones or mandatory sublicensing requirements, and incentives may be needed for developing tests for rare gene disorders. "There isn't a tech-transfer office that isn't aware of the Myriad case," she says, "but licensing people and inventors would like the flexibility to treat each case appropriately." Brendan Borrell 